\title{
First record of coralline fungal disease (CFD) in the Indian Ocean
}

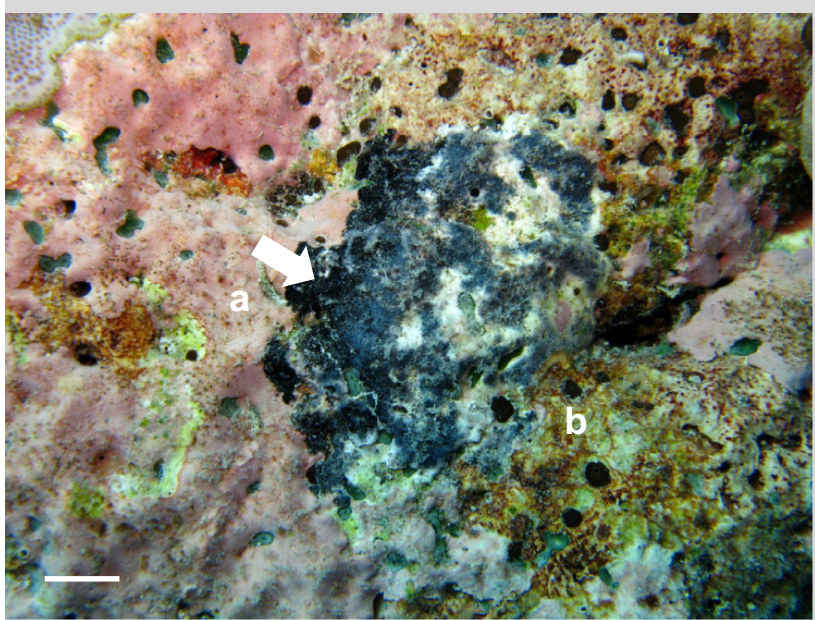

Fig. 1 Field signs of CFD affecting crustose coralline algae (Porolithon sp.) at Ile de la Passe Island, Peros Banhos Atoll, Chagos Archipelago, in April 2018 (fore reef habitat, $\sim 8 \mathrm{~m}$ depth). The active lesion (white arrow) appears as a black/grey mat that tends to radiate out across the surface of the CCA crust. The CCA tissu remains healthy on the leading edge of the lesion (a) but is quickly colonized by microalgae and turf algae following necrosis (b). These field signs are consistent with CFD descriptions from the Pacific Ocean (Vargas-Ángel 2010) that have been confirmed as being caused by a fungal infection using histopathology (Williams et al. 2014). White scale bar $=1 \mathrm{~cm}$

density at these locations ( $>50 \%$ host CCA cover). The coral reefs of the Chagos Archipelago suffered from back-to-back ocean warming events in 2015, 2016 and 2017 that have reduced live hard coral cover. The high densities of CFD recorded here may represent a residual impact of these warming events but whether CFD significantly alters key reef processes such as accretion, coral recruitment and substrate consolidation across the region requires further study.

Acknowledgements We thank the British Indian Ocean Territory (BIOT) for granting access to the Chagos Archipelago and the crew of the Grampian Frontier for logistical support. Funding was provided by the Bertarelli Foundation. On behalf of all authors, the corresponding author states that there is no conflict of interest.

\section{References}

Littler MM, Littler DS (1998) An undescribed fungal pathogen of reef-forming crustose coralline algae discovered in American Samoa. Coral Reefs 17:144

Vargas-Ángel B (2010) Crustose coralline algal diseases in the U.S.-Affiliated Pacific Islands. Coral Reefs 29:943-956

Williams GJ, Price NN, Ushijima B, Aeby GS, Callahan S, Davy SK, Gove JM, Johnson MD, Knapp IS, Shore-Maggio A, Smith JE, Videau P, Work TM (2014) Ocean warming and acidification have complex interactive effects on the dynamics of a marine fungal disease. Proc Roy Soc B 281:20133069

G. J. Williams (iD $(\triangle) \cdot$ R. C. Roche $\cdot$ J. R. Turner

School of Ocean Sciences, Bangor University, Anglesey LL59 5AB, UK

e-mail: g.j.williams@bangor.ac.uk

Received: 8 May 2018/Accepted: 28 May 2018/Published online: 1 June 2018

(C) Springer-Verlag GmbH Germany, part of Springer Nature 2018
Coral Reefs (2018) 37:1243 DOI $10.1007 / \mathrm{s} 00338-018-1704-\mathrm{z}$ 